\title{
Potential anticancer properties of bioactive compounds of Gymnema sylvestre and its biofunctionalized silver nanoparticles
}

This article was published in the following Dove Press journal:

International Journal of Nanomedicine

16 December 2014

Number of times this article has been viewed

\author{
Kantha Deivi Arunachalam \\ Lilly Baptista Arun' \\ Sathesh Kumar Annamalai' \\ Aarrthy M Arunachalam² \\ 'Center for Environmental Nuclear \\ Research, SRM University, Potheri, \\ Tamil Nadu, India; ${ }^{2}$ Division of \\ Educational Services, Kaplan \\ University (Medical), Washington \\ DC, USA
}

Background: Gymnema sylvestre is an ethno-pharmacologically important medicinal plant used in many polyherbal formulations for its potential health benefits. Silver nanoparticles (SNPs) were biofunctionalized using aqueous leaf extracts of $G$. sylvestre. The anticancer properties of the bioactive compounds and the biofunctionalized SNPs were compared using the HT29 human adenoma colon cancer cell line.

Methods: The preliminary phytochemical screening for bioactive compounds from aqueous extracts revealed the presence of alkaloids, triterpenes, flavonoids, steroids, and saponins. Biofunctionalized SNPs were synthesized using silver nitrate and characterized by ultravioletvisible spectroscopy, scanning electron microscopy, energy-dispersive X-ray analysis, Fourier transform infrared spectroscopy, and X-ray diffraction for size and shape. The characterized biofunctionalized $G$. sylvestre were tested for its in vitro anticancer activity against HT29 human colon adenocarcinoma cells.

Results: The biofunctionlized G. sylvestre SNPs showed the surface plasmon resonance band at $430 \mathrm{~nm}$. The scanning electron microscopy images showed the presence of spherical nanoparticles of various sizes, which were further determined using the Scherrer equation. In vitro cytotoxic activity of the biofunctionalized green-synthesized SNPs (GSNPs) indicated that the sensitivity of HT29 human colon adenocarcinoma cells for cytotoxic drugs is higher than that of Vero cell line for the same cytotoxic agents and also higher than the bioactive compound of the aqueous extract.

Conclusion: Our results show that the anticancer properties of the bioactive compounds of G. sylvestre can be enhanced through biofunctionalizing the SNPs using the bioactive compounds present in the plant extract without compromising their medicinal properties.

Keywords: Gymnema sylvestre, gymnemic acid, biofunctionalized silver nanoparticles, anticancer activity, HT29 cell line

\section{Introduction}

For treatment of various diseases, bioactive components from medicinal plants that are similar to chemical compounds are used. ${ }^{1}$ In recent years, the use of ethno-botanical information in medicinal plant research has gained considerable attention in some segments of the scientific community. ${ }^{2}$ In one of the ethno-botanical surveys of medicinal plants commonly used by the Kani tribals in Tirunelveli hills of the Western Ghats in Tamil Nadu, India, it was revealed that Gymneme sylvestre is the most important species based on its use. ${ }^{2}$ The use of plant parts and isolated phytochemicals for the prevention and treatment of various health ailments has been in practice for many decades. $^{3}$

G. sylvestre R. Br, commonly known as "Meshasringi", is distributed over most of India and has a reputation in traditional medicine as a stomachic, diuretic, and a remedy 
to control diabetes mellitus. G. sylvestre $\mathrm{R}$. $\mathrm{Br}^{4}$ is a woody, climbing plant that grows in the tropical forests of Central and Southern India and in parts of Asia. ${ }^{5}$ It is a pubescent shrub with young stems and branches, and has a distichous phyllotactic opposite arrangement pattern of leaves which are $2.5-6 \mathrm{~cm}$ long and are usually ovate or elliptical. The flowers are small, yellow, and in umbellate cymes, and the follicles are terete, lanceolate, and up to 3 inches in length. ${ }^{6}$

In homeopathy, as well as in folk and ayurvedic medicine, G. sylvestre has been used for diabetes treatment. ${ }^{7}$ G. sylvestre has bioactive components that can cure asthma, eye ailments, snakebite, piles, chronic cough, breathing troubles, colic pain, cardiopathy, constipation, dyspepsia, hemorrhoids, and hepatosplenomegaly, as well as assist in family planning. ${ }^{8}$ In addition, it also possesses antimicrobial, ${ }^{9}$ antitumor, ${ }^{5}$ anti-obesity, ${ }^{10}$ anti-inflammatory, ${ }^{11}$ anti-hyperglycemic, ${ }^{12}$ antiulcer, anti-stress, and antiallergic activity. ${ }^{13}$

The presence of flavonoids, saponins, anthraquinones, quercitol, and other alkaloid have been reported in the flowers, leaves, and fruits of G. sylvestre. ${ }^{14}$ The presence of other therapeutic agents, such as gymnemagenin, gymnemic acids, gymnemanol, and $\beta$-amyrin-related glycosides, which play a key role in therapeutic applications, have also been reported. The focus of the present work is to assess the potential therapeutic medicinal value of this herb and to understand/enhance the mechanistic action of their bioactive components. ${ }^{14}$

G. sylvestre contains triterpenes, saponins, and gymnemic acids belonging to the oleane and dammarene classes. ${ }^{15,16}$ The plant extract has also tested positive for alkaloids, acidic glycosides, and anthraquinone derivatives. Oleanane saponins are gymnemic acids and gymnema saponins, while dammarene saponins are gymnemasides.

As reported by Thakur et $\mathrm{al}^{14}$ the aqueous extracts of the $G$. sylvestre leaves showed the presence of gymnemic acids I-VI, while the saponin fraction of the leaves tested positive for the presence of gymnemic acids XV-XVIII. The gymnemic acid derivative of gymnemagenin was elucidated from the fraction VIII-XII, which is responsible for the antidiabetic activity, and the fraction VIII stimulates the pancreas for insulin secretion. The novel D-glucoside structure with anti-sweet principle is present in the $\mathrm{I}-\mathrm{V}$ saponin fraction. The presence of pentatriacontane, $\alpha$ - and $\beta$-chlorophylls, phytin, resins, D-quercitol, tartaric acid, formic acid, butyric acid, lupeol, and stigmasterol has been reported as other plant constituents of $G$. sylvestre, ${ }^{14}$ while the extract has also been tested positive for alkaloids. ${ }^{13,17}$

Sharma et al have reported the antioxidant activity of oleane saponins from $G$. sylvestre plant extract and determined the $\mathrm{IC}_{50}$ values for 2,2-diphenylpicrylhydrazyl (DPPH) scavenging, superoxide radical scavenging, inhibition of in vitro lipid peroxidation, and protein carbonyl formation as $238 \mu \mathrm{g} / \mathrm{mL}, 140 \mu \mathrm{g} / \mathrm{mL}, 99 \mu \mathrm{g} / \mathrm{mL}$, and $28 \mu \mathrm{g} / \mathrm{mL}$, respectively, which may be due to the presence of flavonoids, phenols, tannins, and triterpenoids. ${ }^{18}$ The enhanced radiation ( 8 Gy)-induced augmentation of lipid peroxidation and depletion of glutathione and protein in mouse brain were reported by Sharma et al ${ }^{18}$ using multiherbal ayurvedic formulations containing extracts of G. sylvestre, such as "Hyponidd" and "Dihar". They also demonstrated the antioxidant activity by increasing the levels of superoxide dismutase, glutathione, and catalase in rats through in vivo studies. ${ }^{19}$

Kang et $\mathrm{al}^{20}$ proved the role of antioxidants from $G$. $s y l$ vestre in diabetic rats using ethanolic extracts. Using several antioxidant assays, eg, thiobarbituric acid assay with slight modifications, egg yolk lecithin or 2-deoxyribose (associated with lipid peroxidation) assay, superoxide dismutase-like activity assay, and 2,2'-azinobis (3-ethylbenzothiazoline-6sulfonic acid) assay.

The potent anticancer activity of $G$. sylvestre against the human lung adenocarcinoma cell lines (A549) and human breast carcinoma cell lines (MCF7) using alcoholic extracts of the herb has been reported by Srikant et al. ${ }^{21}$ Also, Amaki et $\mathrm{al}^{22}$ reported the inhibition of the breast cancer resistance protein using the alcoholic extract of G. sylvestre.

Many plant-derived saponins, eg, ginsenosides, soyasaponins, and saikosaponins, have been found to exhibit significant anticancer activity. The anticancer activity of gymnemagenol on HeLa cancer cell lines in in vitro conditions was determined by the MTT cell proliferation assay for cytotoxic activity of saponins. Using $5 \mu \mathrm{g} / \mathrm{mL}, 15 \mu \mathrm{g} / \mathrm{mL}$, $25 \mu \mathrm{g} / \mathrm{mL}$, and $50 \mu \mathrm{g} / \mathrm{mL}$ concentrations of gymnemagenol, the $\mathrm{IC}_{50}$ value was found to be $37 \mu \mathrm{g} / \mathrm{mL}$ after 96 hours. The isolated bioactive constituent, gymnemagenol, showed a high degree of inhibition to HeLa cancer cell line proliferation, and saponins were not found to be toxic to the growth of normal cells under in vitro conditions. ${ }^{23}$

Already many researchers have reported that the leaves of $G$. sylvestre lower blood sugar, stimulate the heart, uterus, and circulatory systems, and exhibit anti-sweet and hepatoprotective activities. ${ }^{20,24-31}$ Administration of G. sylvestre extract to diabetic rats increased superoxide dismutase activity and decreased lipid peroxide by either directly scavenging the reactive oxygen species, due to the presence of various antioxidant compounds, or by increasing the synthesis of antioxidant molecules (albumin and uric acid). ${ }^{24,30,32}$ 
Therefore, in this study, an attempt was made to synthesize the silver nanoparticles (SNPs) from aqueous extracts of the G. sylvestre leaves. These green-synthesized SNPs (GSNPs) of G. sylvestre were examined by ultravioletvisible (UV-vis) spectroscopy, scanning electron microscopy (SEM), energy dispersive X-ray analysis (EDAX), Fourier transform infrared spectroscopy (FTIR), and X-ray diffraction (XRD) analysis for studying their size and shape. The synthesized and well-characterized nanoparticles (NPs) were tested for their cytotoxicity effect. Our findings clearly demonstrate that it is indeed possible to have a much greener way to synthesize SNPs without compromising their antibacterial properties and thus plant extracts may prove to be a good alternative to obtain such NPs with improved antibacterial and antiviral properties for diabetic wound healing applications. Goix et $\mathrm{al}^{33}$ and Boholm and Arvidsson ${ }^{34}$ have pointed out that silver is either beneficial or harmful in relation to four main values: the environment, health, sewage treatment, and product effectiveness. As reported by Barua et al ${ }^{35}$ poly(ethylene glycol)-stabilized colloidal SNPs showed the nonhazardous anticancer and antibacterial properties. Jin et $\mathrm{al}^{36}$ have reported the therapeutic applications of plant-extract-based scaffolds for wound healing and skin reconstitution studies.

\section{Materials and methods Collection of plants}

Fresh leaves of $G$. sylvestre from plants of same age group of a single population were collected from the experimental Herbal Garden, Tamil University, Thanjavur, Tamil Nadu, India, in July, 2010. The herbarium was prepared for authentication (Ref No: SRM $\backslash$ CENR $\backslash P T C \backslash 2010 \backslash 03$ ), and taxonomic identification was done by Dr Jayaraman, Professor, Department of Botany, Madras Christian College, Tambaram, Chennai, Tamil Nadu. The herb sample is maintained in the research laboratory for further reference.

\section{Preparation of aqueous extract}

The leaves of G. sylvestre were washed with distilled water to remove the dirt and further washed with mild soap solution and rinsed thrice with distilled water. The leaves were blotdried with tissue paper and shade dried at room temperature for 2 weeks. After complete drying, the leaves were cut into small pieces and powdered in a mixer and sieved using a $20-\mu \mathrm{m}$ mesh sieve to get a uniform size range for further studies. Twenty grams of the sieved leaf powder was added to $100 \mathrm{~mL}$ of sterile distilled water in a 500-mL Erlenmeyer flask and boiled for 5 minutes. The flask was kept under continuous dark conditions at $30^{\circ} \mathrm{C}$ in a shaker. The extract was filtered and stored in an airtight container and protected from sunlight for further use. ${ }^{37}$

\section{Qualitative and quantitative phytochemical analysis}

The qualitative phytochemical analysis of $G$. sylvestre extracts were performed following the methods of Parekh and $\mathrm{Chanda}^{38}$ to determine the presence of alkaloids (Mayer, Wagner, Dragendorff), flavonoids (alkaline reagent, Shinoda), phenolics (lead acetate, alkaline reagent test), triterpenes (Liberman-Burchard test), saponins (foam test), and tannins (gelatin). ${ }^{39}$ The results were qualitatively expressed as positive $(+)$ or negative $(-) .{ }^{40}$ The chemicals used for the study were purchased from Sigma-Aldrich (Chennai, India).

Phytochemical quantitative analyses are described briefly in our previous paper. ${ }^{13}$ The total phenolic content was measured using the Folin-Ciocalteu colorimetric method. The flavonoids were estimated using aluminum chloride colorimetric method. Gallic acid was used as standard for the analysis of total antioxidant capacity, and the DPPH radical scavenging activity was done following the methods described by Blios. ${ }^{41}$

\section{Synthesis of SNPs}

Silver nitrate $\left(\mathrm{AgNO}_{3}\right)$ was purchased from Sigma-Aldrich (St Louis, MO, USA), and all solutions were freshly made for the synthesis of SNPs. The aqueous leaf extract of G. sylvestre was used for the bioreduction synthesis of the NPs. The SNPs were synthesized by adding $5 \mathrm{~mL}$ of plant extract to $15 \mathrm{~mL}$ of $1 \mathrm{mM}$ aqueous $\mathrm{AgNO}_{3}$ solution in a 250-mL Erlenmeyer flask and incubated in a rotary shaker at $150 \mathrm{rpm}$ in dark. The synthesis of NPs was confirmed spectrophotometrically at every 30 -minute interval till no reduction was observed. The reduction was observed by the color change in the colloidal solution, which confirmed the formation of SNPs. ${ }^{42,43}$

\section{Characterization of SNPs}

The GSNPs were characterized periodically by measuring the bioreduction of $\mathrm{AgNO}_{3}$ using a UV-vis 3000+ doublebeam spectrophotometer (Lab India, Maharashtra, India). The spectrometric range was $200-800 \mathrm{~nm}$, and scanning interval was $0.5 \mathrm{~nm}$.

The surface morphology of the biofunctionalized SNPs was characterized by high-resolution SEM analysis (JSM-5600LV; JEOL, Tokyo, Japan) and the elemental 
compositions were determined by EDAX analysis (S-3400N; Hitachi, Tokyo, Japan). The functional characterization of biomolecules present in the GSNPs from the leaf extract of G. sylvestre was done by FTIR spectrometry (RX1; PerkinElmer, Waltham, MA, USA). ${ }^{44}$

The crystal lattice and the size of the synthesized NPs were determined by XRD measurements using an XRD-6000 X-ray diffractometer (Shimadzu, Kyoto, Japan). The crystallite domain size was calculated from the width of the XRD peaks, as described in our previous papers. ${ }^{17,45-47}$

\section{In vitro anticancer activity}

\section{Cell line and culture medium}

Vero cell line (derived from the normal kidney of adult monkeys) and human adenocarcinoma colon HT29 cells were purchased from the National Center for Cell Sciences, Pune, India. The cells were cultured under standard conditions in Dulbecco's Modified Eagle Medium (DMEM), supplemented with $10 \%$ heat-inactivated fetal bovine serum (FBS), $100 \mathrm{U} / \mathrm{mL}$ of penicillin, and $100 \mathrm{U} / \mathrm{mL}$ of streptomycin in a humidified incubator set at $37^{\circ} \mathrm{C}$ with $5 \% \mathrm{CO}_{2}{ }^{17}$

\section{Cell viability by MTT assay}

MTT assay was performed to determine the cytotoxic properties of biofunctionalized SNPs against HT29 cell lines by adding $1 \times 10^{5}$ cells/well in 12 -well plates and incubated with various concentrations of biofunctionalized particles ( $83 \mu \mathrm{g} / \mathrm{mL}, 84 \mu \mathrm{g} / \mathrm{mL}$, and $85 \mu \mathrm{g} / \mathrm{mL})$. Vero cells were used as a monolayer for culturing the HT29 cells. The cell lines were seeded in 96-well tissue culture plates and the appropriate concentrations of GSNP stock solutions were added to the cultures to obtain the respective concentration of the NPs and incubated for 48 hours at $37^{\circ} \mathrm{C}$. The untreated cells were used as control. The incubated cultured cells were subjected to MTT colorimetric assay. All assays were performed in triplicate, and the aqueous leaf extract of the G. sylvestre were also similarly assayed for the anticancer activity for comparison. ${ }^{17,48}$

\section{Morphological changes}

The cytotoxicity effects were observed using an inverted microscope, and the morphological changes were photographed. ${ }^{49}$

\section{Results}

\section{Phytochemical screening of G. sylvestre leaf extract}

The preliminary phytochemical screening of aqueous extracts of $G$. sylvestre revealed the presence of alkaloids, phenols,
Table I Phytochemical screening of leaf extract of Gymnema sylvestre

\begin{tabular}{ll}
\hline Compound & Aqueous extract \\
\hline Alkaloids & + \\
Triterpenoids & + \\
Glycosides & - \\
Saponins & + \\
Tannins phenols & + \\
Flavonoids & + \\
Steroids & + \\
\hline
\end{tabular}

Notes: +, present; -, absent.

flavonoids, sterols, tannins, and triterpenes (Table 1). As shown in Table 2, $125.62 \pm 26.84 \mu \mathrm{g} / \mathrm{g}$ of total flavonoids, $285.23 \pm 1.11 \mu \mathrm{g} / \mathrm{g}$ of total phenols, and $111.53 \pm 15.13 \mu \mathrm{g} / \mathrm{g}$ of tannin were present in the aqueous extract of $G$. sylvestre. The flavonoids and phenolic compounds exhibited a wide range of biological activities, such as antioxidant and lipid peroxidation inhibition. ${ }^{13}$

The estimated total antioxidant activity was 9.13 $0.04 \mu \mathrm{g} / \mathrm{g}$ and the DPPH radical scavenging activity was $52.14 \% \pm 0.32 \%$ (Table 2 ).

\section{Characterization of biofunctionalized SNPs}

The color change observed in the aqueous silver nitrate solution showed that the SNPs were formed rapidly within 30 minutes of incubation of the plant extract with aqueous $\mathrm{AgNO}_{3}$ solution. The colorless solution changed to ruby red, confirming the formation of SNPs (Figure 1). The intensity of the red color increased with time because of the excited surface plasmon resonance effect and reduced $\mathrm{AgNO}_{3}$. The control aqueous $\mathrm{AgNO}_{3}$ solution (without leaf extract) showed no change of color with time and was taken as the blank reference.

UV-vis spectrometry is a reliable and reproducible technique that can be used to accurately characterize the metal NPs though it does not provide direct information regarding the particle sizes. The surface plasmon bands

Table 2 Estimation of phytochemical compounds of leaf extract of Gymnema sylvestre

\begin{tabular}{ll}
\hline Bioactive compounds & $\mu \mathrm{g} / \mathrm{g}$ \\
\hline Total antioxidant $^{\mathrm{a}}$ & $9.13 \pm 0.04$ \\
Flavonoids $^{\mathrm{b}}$ & $125.62 \pm 26.84$ \\
Tannin $^{\mathrm{c}}$ & $1 \mathrm{II} .53 \pm 15.13$ \\
Total phenol content $^{\mathrm{d}}$ & $285.23 \pm 1.1 \mathrm{I}$ \\
Free radical scavenging $^{\mathrm{d}}$ & $52.14 \pm 0.32$ \\
\hline
\end{tabular}

Notes: All the values given are means of triplicates. Data presented as the mean \pm

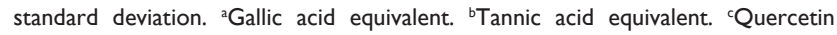
equivalent. ${ }^{d}$ Catechin equivalent. 


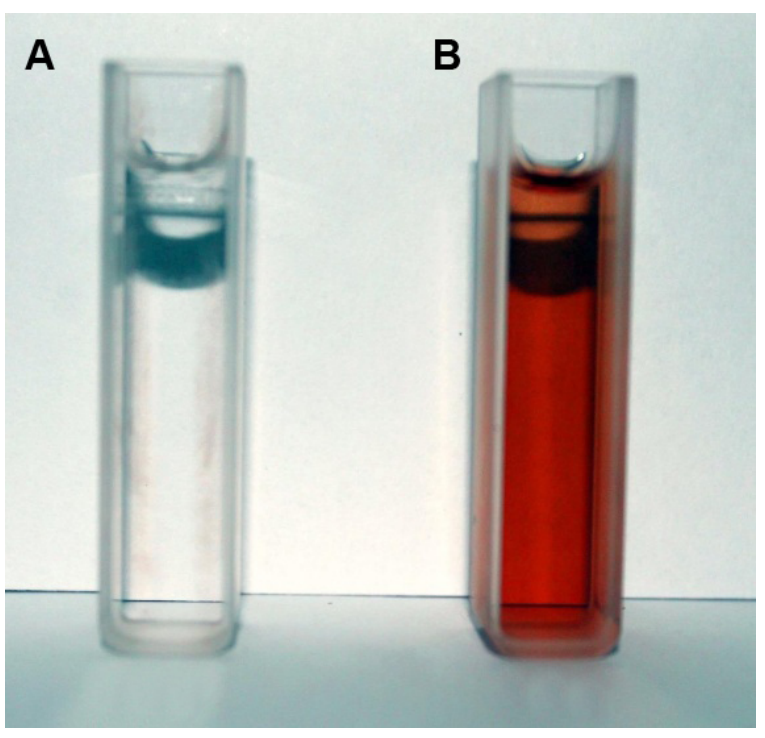

Figure I Surface plasmon resonance of silver nanoparticles.

Notes: (A) silver nitrate solution; (B) green-synthesized silver nanoparticles in ruby red color after 30 minutes.

(absorbance spectra) are influenced by the size and shape of the NPs produced, along with the dielectric constant of the surrounding media.

Figure 2 shows the time-dependent intensity of the absorption band, which reached its maximum peak at 12 hours, after which no further change in the spectrum was observed indicating that the precursors had been consumed. Initially, the UV-vis spectrum did not show evidence of any absorption in the region 350-600 nm, but after the addition of extract a distinct band was observed at $432 \mathrm{~nm}$.

When silver nitrate was added to the aqueous plant extract of $G$. sylvestre, it was reduced to SNPs by the aldehyde group present in the flavonoids $(125.6 \mu \mathrm{g} / \mathrm{g})$, which was further oxidized to the carboxyl group. Also, the carboxyl groups of

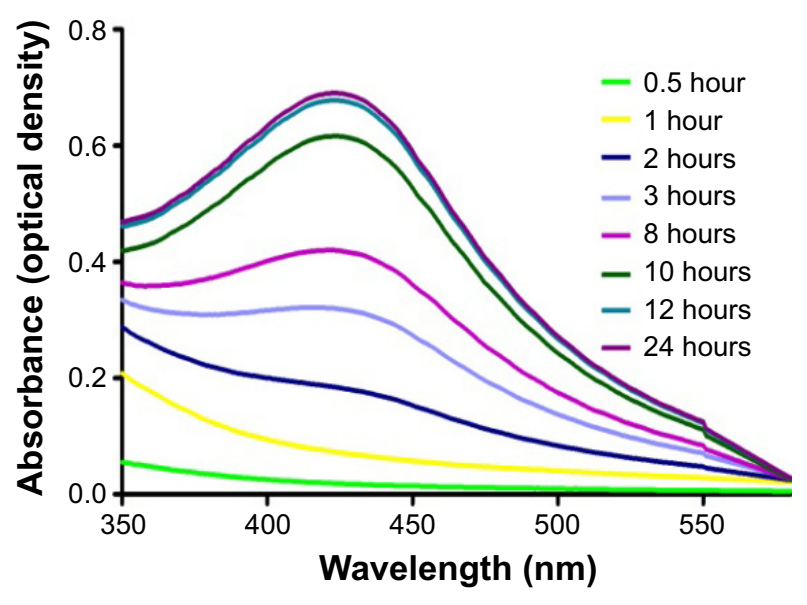

Figure 2 Time-dependent absorption spectra of silver nanoparticles after the bioreduction of silver in the aqueous extract of Gymnema sylvestre. the phenols from the G. sylvestre extract $(285.23 \mu \mathrm{g} / \mathrm{g})$ acted as a surfactant to attach the major phytochemicals from the plant extract to the surface of the SNPs. Our previous study on the synthesis of SNPs using aqueous extracts of Memecylon edule, ${ }^{37}$ Memecylon umbellatum, ${ }^{47}$ Chrysopogon zizanioides ${ }^{46}$ and Indigofera aspalathoides ${ }^{50}$ showed that the color of the reaction mixture during the formation of GSNPs changed to ruby red color from colorless/straw color. Our results are also comparable with the other available reports for plant-extractmediated synthesis of SNPs.

From Figure 3, it is clear that the synthesized SNPs were approximately spherical and of different sizes. The SEM images in the figure clearly indicated a thin layer of phytochemicals from the plant extract covering the synthesized SNPs. Mostly the total phenolic content, flavonoids, and tannins were responsible for the bioreduction of the SNPs. In this green synthesis, the phytochemicals from the plant extract acted as a surfactant to prevent the aggregation of the synthesized SNPs. The SEM images of our earlier research had revealed that this biologically eco-friendly synthesis of NPs utilizing the leaf extracts of M. edule, ${ }^{37} \mathrm{C}$. zizanioides, ${ }^{46}$ and $M$. umbellatum ${ }^{47}$ showed no aggregation due to the biomolecules from the plant extract. And the mechanism behind this particle formation with no aggregation may be the spontaneous nucleation and isotropic growth of NPs along with the plant extract. As these chains grow in diameter with increasing silver deposition, spherical particles break off from these structures forming nanospherical particles which can be typically observed from this synthesis. ${ }^{51}$

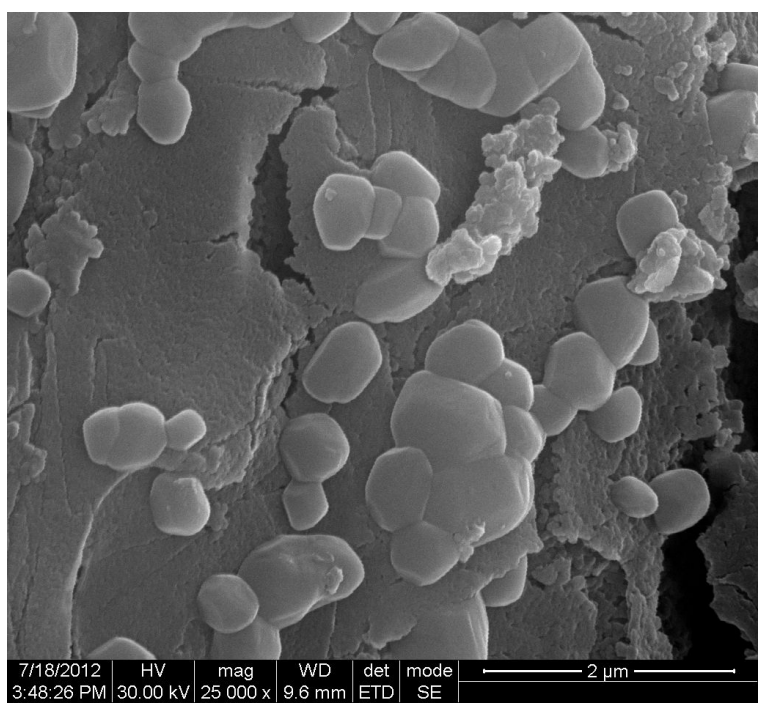

Figure 3 Scanning electron microscopic image of green silver nanoparticles synthesized by reduction of aqueous $\mathrm{AgNO}_{3}$ ions using aqueous extract of Gymnema sylvestre. Abbreviations: HV, high voltage; WD, working distance; mag, magnification; ETD, Everhart-Thornley detector. 
The elemental composition of green-synthesized AgNPs was analyzed through EDAX. These measurements confirmed the presence of the elementary silver signal of the SNPs. The vertical axis displays the number of $\mathrm{X}$-ray counts and the horizontal axis displays the energy in $\mathrm{keV}$.

The EDAX spectrum of the biofunctionalized SNPs in Figure 4 clearly shows the strong signals from silver atoms along with the weaker signals from carbon and oxygen present from biomolecules of the plant extract. The elemental silver peak at $2-4 \mathrm{keV}$, which is the major emission peak specified for metallic silver, with minor peaks of $\mathrm{C}$ and $\mathrm{O}$ were also seen due to the capping of Ag NPs by the biomolecules of G. sylvestre leaf extract, and the absence of other peaks evidenced the purity of the Ag NPs.

FTIR analysis in Figure 5 shows that the SNPs produced by $G$. sylvestre extract were coated by phytocompounds and secondary metabolites such as saponins, terpenoids, and gymnemagenin derivative of gymnemic acid containing the functional groups of amines, aldehydes, carboxylic acids, and alcohols.

The presence of the amide linkages seen in Figure 5 suggests that the different functional groups of the proteins present in the plant extracts might be capping the NPs and playing an important role in the stabilization of the green NPs formed. The band at $1,443 \mathrm{~cm}^{-1}$ was assigned to the methylene scissoring vibrations of proteins, and the bands located at $1,318 \mathrm{~cm}^{-1}$ and $1,089 \mathrm{~cm}^{-1}$ are due to the $\mathrm{C}-\mathrm{N}$ stretching vibration of aromatic and aliphatic amines, respectively, which agrees with earlier reports of Suman et al. ${ }^{52}$

The positions of these bands were comparable to those reported for phytochemicals reported in the $G$. sylvestre extract as total phenols, flavonoids, and tannins (Table 2). Thus, we can confirm that the nanocapping of the phytochemicals from the G. sylvestre extract is responsible for the reduction and subsequent stabilization of the SNPs.

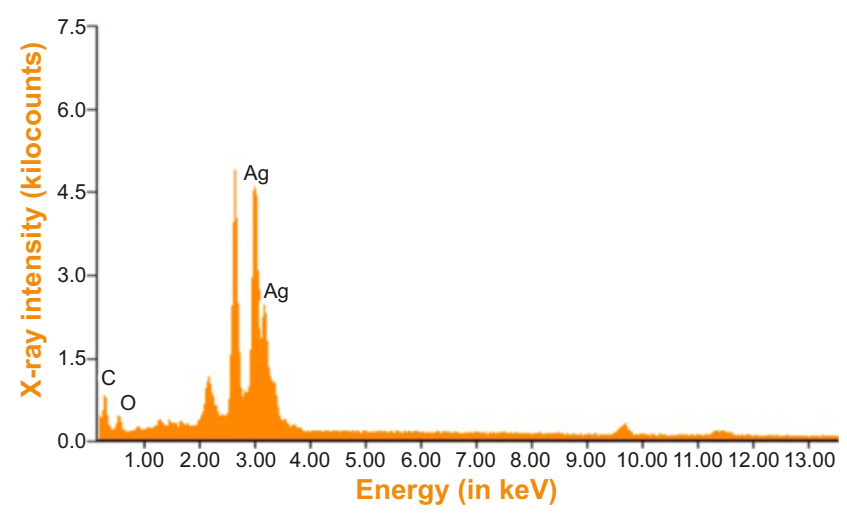

Figure 4 Energy-dispersive X-ray spectrum of green silver nanoparticles.

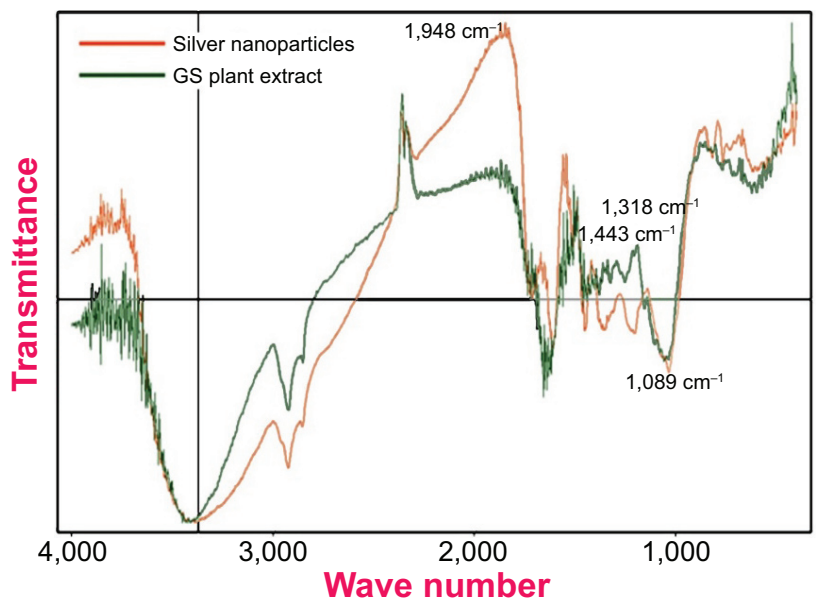

Figure 5 Fourier transform infrared spectroscopy spectrum of green-synthesized silver nanoparticles along with the plant extract of Gymnema sylvestre (GS).

The absorption bands that appear in the IR spectrum of the aqueous extract could also be seen in the IR spectra of phyto-capped Ag NPs, confirming the role of the phyto constituents (mostly gymnemic acid) in protecting the Ag NPs from aggregation.

Also, during our repeated experiments there were no batch-to-batch variations in size, regardless of the isotopic composition, and the particles diameters of the SNPs formed were known to a high degree of accuracy. A detailed study on the large-scale synthesis and elemental composition on the synthesized NPs can be carried out using inductively coupled plasma mass spectrometry to obtain reproducible compositions in every batch. In future, the elemental analysis can be carried out as described earlier by other researchers. . $3,54^{2}$

XRD analysis of NPs represented in Figure 6 shows several size-dependent features leading to irregular peak position, height, and width. XRD was mainly carried out to study the crystalline nature of the green-synthesized $G$. sylvestre SNPs. From the figure, the GSNPs are seen to exhibit monocrystallinity. The XRD peaks at $38.2^{\circ}, 44.5^{\circ}$, $64.7^{\circ}$, and $77.7^{\circ}$ can be indexed to the [111], [200], [220], and [311] planes, indicating that the SNPs are highly crystalline. Similar results were reported for Abelmoschus esculentus, Citrus limon, Citrus reticulate, and Citrus sinensis ${ }^{55,56}$ and in our previous studies using C. zizanioides. ${ }^{46}$

Table 3 shows the characteristic features of the GSNPs using various plant parts of different plant species reported by various researchers along with our previous reports.

\section{In vitro anticancer activity}

From Figure 7, it can be observed that, as the concentration of the GSNPs increased, the percentage of viable cells decreased 


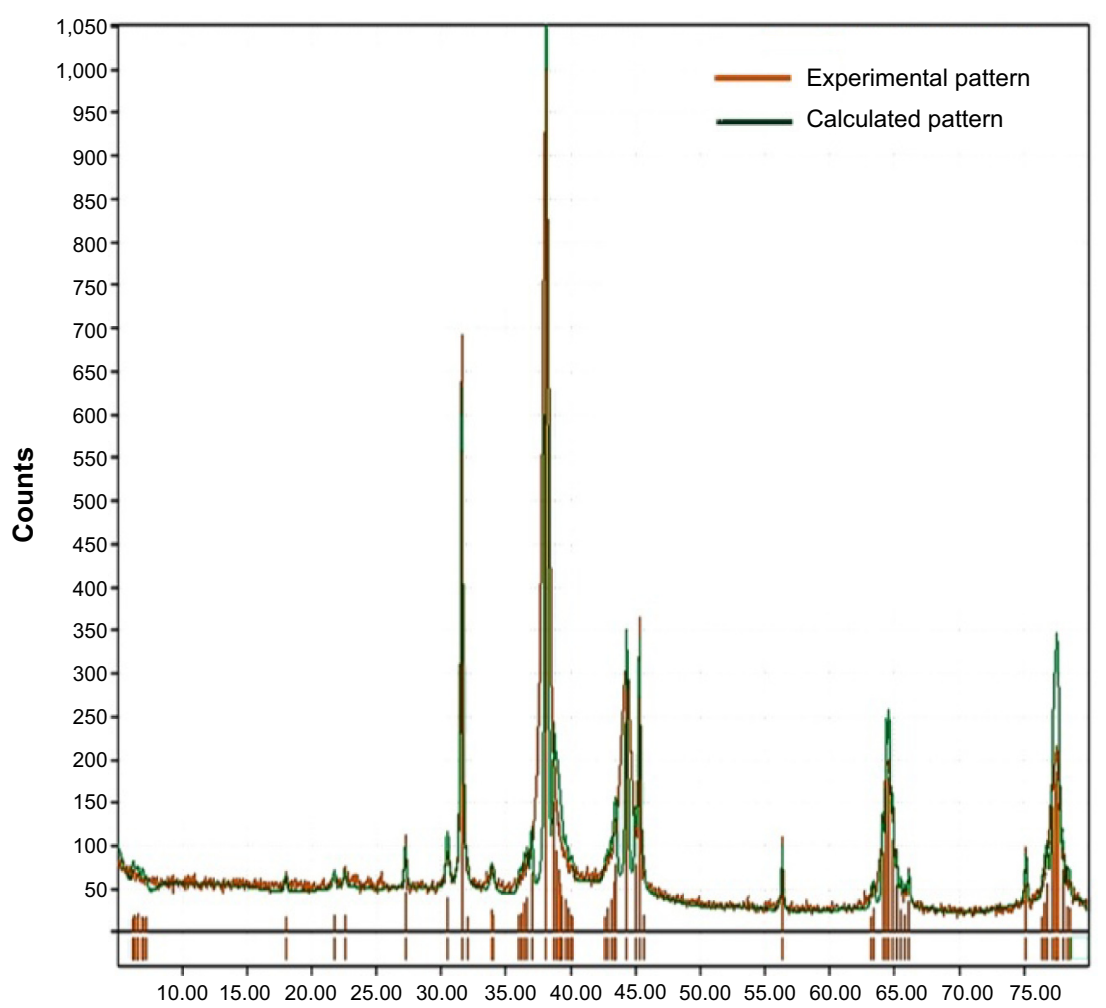

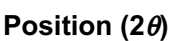

Figure 6 X-ray diffraction spectrum of green-synthesized silver nanoparticles.

Table 3 Comparative chart of the characterization of green-synthesized silver nanoparticles using various plant extracts

\begin{tabular}{|c|c|c|c|c|c|c|}
\hline Plant name & $\begin{array}{l}\text { UV-vis peak } \\
(\mathrm{nm})\end{array}$ & Color change & Shape & $\begin{array}{l}\text { Size } \\
(\mathrm{nm})\end{array}$ & $\begin{array}{l}\text { Reaction } \\
\text { time }\end{array}$ & Reference \\
\hline Camellia sinensis & 436 & $\begin{array}{l}\text { Colorless to light to } \\
\text { dark brown }\end{array}$ & Spherical & 4.06 & - & Loo et $\mathrm{al}^{57}$ \\
\hline Dioscorea bulbifera & 450 & Intense brown coloration & Nano-triangle & $8-20$ & $5 \mathrm{~h}$ & Ghosh et $\mathrm{al}^{58}$ \\
\hline Pulicaria glutinosa & 427 & Light yellow to dark brown & Spherical & $40-60$ & $20 \mathrm{~h}$ & Khan et $\mathrm{al}^{59}$ \\
\hline Curcuma longa & 415 & Colorless to golden yellow & Spherical & $3.66-8.94$ & $24 \mathrm{~h}$ & Shameli et $\mathrm{al}^{60}$ \\
\hline Chrysanthemum morifolium & 430 & Colorless to yellow brown & Spherical & $20-50$ & - & He et $\mathrm{al}^{61}$ \\
\hline Rhinacanthus nasutus & 437 & Colorless to yellowish brown & Irregular & 22 & $24 \mathrm{~h}$ & Pasupuleti et al ${ }^{62}$ \\
\hline Chrysanthemum indicum & 435 & Colorless to reddish brown & Spherical & $37.7 I-7 I .99$ & - & Arokiyaraj et al ${ }^{63}$ \\
\hline Chrysopogon zizanioides & 420 & Colorless to brown color & Cubic & $85-110$ & $24 \mathrm{~h}$ & Arunachalam and Annamalai ${ }^{46}$ \\
\hline Memecylon umbellatum & 440 & Colorless to brown color & Spherical & $15-20$ & $24 \mathrm{~h}$ & Arunachalam et $\mathrm{al}^{47}$ \\
\hline Solanum torvum & 430 & Yellow to brown color & Spherical & $5-50$ & $24 \mathrm{~h}$ & Ramamurthy et al ${ }^{64}$ \\
\hline Vitex negundo $L$. & 430 & Yellowish brown & Spherical & $5-47$ & $4 \mathrm{~h}$ & Prabhu et $a^{65}$ \\
\hline Aloe vera & 430 & $\begin{array}{l}\text { Yellow, golden brown, } \\
\text { and brown }\end{array}$ & Spherical & 20 & $20 \min$ & Zhang et $\mathrm{al}^{66}$ \\
\hline Ixora coccinea & 430 & Colorless to brown & Spherical & $13-57$ & $12 \mathrm{~h}$ & Karuppiah and Rajmohan ${ }^{67}$ \\
\hline Adhatoda vasica & 421 & Blackish brown colored & Spherical & $113-633$ & - & Nazeruddin et al ${ }^{68}$ \\
\hline Boerhaavia diffusa & 410 & Colorless to brown & Spherical & 25 & - & Vijay Kumar et $a^{69}$ \\
\hline Prosopis juliflora & 420 & Colorless to brown & Cubic & $11-19$ & $5 \mathrm{~min}$ & Raja et $\mathrm{al}^{70}$ \\
\hline Catharanthus roseus & 410 & Colorless to brown yellow & Spherical & $35-55$ & $60 \min$ & Ponarulselvam et $\mathrm{al}^{71}$ \\
\hline Moringa oleifera & 420 & Yellow to reddish brown & $\begin{array}{l}\text { Spherical and } \\
\text { pentagonal }\end{array}$ & 40 & $16 \mathrm{~h}$ & Vasanth et $\mathrm{al}^{48}$ \\
\hline Morinda citrifolia & 413 & Light yellow to brown & Oval & $32-55$ & $12 \mathrm{~h}$ & Suman et $\mathrm{al}^{72}$ \\
\hline Artemisia nilagirica & - & Clear to yellowish brown & Square & 70-90 & - & Vijay Kumar et $\mathrm{al}^{73}$ \\
\hline Indigofera aspalathoides & 420 & Colorless to yellow & Square & $45-69$ & $8 \mathrm{~h}$ & Arunachalam et $\mathrm{al}^{50}$ \\
\hline Saraca asoca & 424 & Colorless to brownish gray & Irregular & $87-102$ & $24 \mathrm{~h}$ & Meenakumari et $\mathrm{al}^{74}$ \\
\hline
\end{tabular}

Abbreviations: $h$, hours; min, minutes; UV, ultraviolet; vis, visible spectrum. 


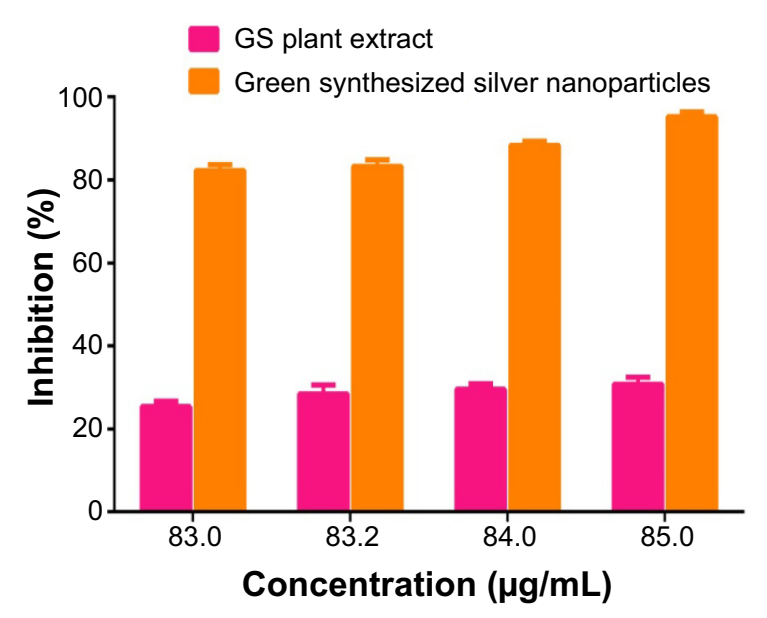

Figure 7 Anticancer activity of the green-synthesized silver nanoparticles. Abbreviation: GS, Gymnema sylvestre.

in the cytotoxicity studies by MTT assay. The GSNPs were taken up by mammalian cells through different mechanisms such as pinocytosis, endocytosis, and phagocytosis. ${ }^{75}$ Once the NPs enter the cells, they interact with the cellular materials and cause DNA damage and cell death.
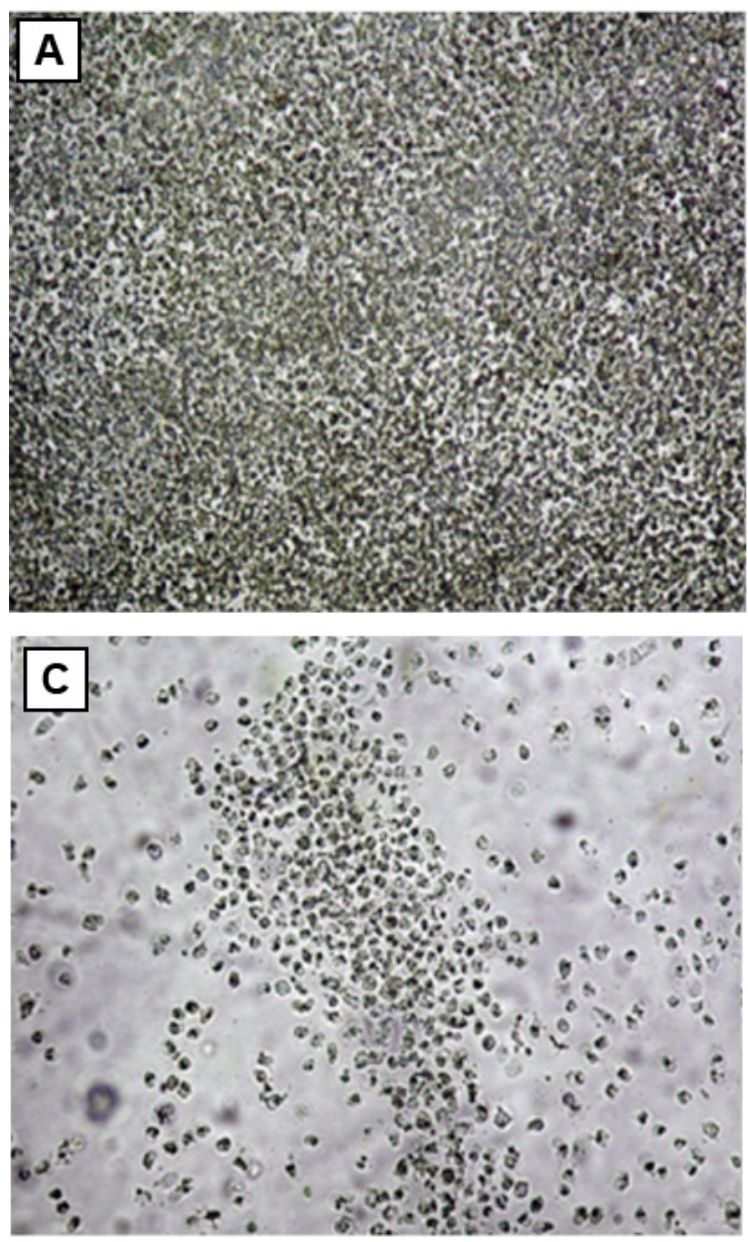

The GSNPs at $85 \mu \mathrm{g} / \mathrm{mL}$ concentration showed $95.23 \%$ inhibition of HT2 9 cell growth. The concentration of the NPs was chosen based on the TC $\mathrm{ID}_{50}$ value (results not shown). Another promising result was that $G$. sylvestre plant extracts alone at $85 \mu \mathrm{g} / \mathrm{mL}$ concentration showed $30.77 \%$ inhibition of HT29 cell lines growth. From our results, it can be concluded that the GSNPs could have induced intracellular reactive oxygen species generation, which can be evaluated using intracellular peroxide-dependent oxidation, and caused cell death. The control cells were clustered, healthy, and viable cells (Figure 8A), whereas the HT29 cells' proliferation was significantly inhibited by GS (Figure $8 \mathrm{~B}$ ). The SNP-treated cells showed increased apoptotic morphological changes (Figure 8C), also the clearly visible cell debris in Figure 8D is due to cell death by $85 \mu \mathrm{g} / \mathrm{mL}$ SNP treatment.

These results indicate that the sensitivity of HT29 human colon cancer cell line for cytotoxic drugs is higher than that of the Vero cell line for the same cytotoxic agents. Sahu et al ${ }^{76}$ have reported the presence of four new tritepenoid saponins, namely gymnemasins $\mathrm{A}, \mathrm{B}, \mathrm{C}$, and $\mathrm{D}$, from the leaves of $G$.
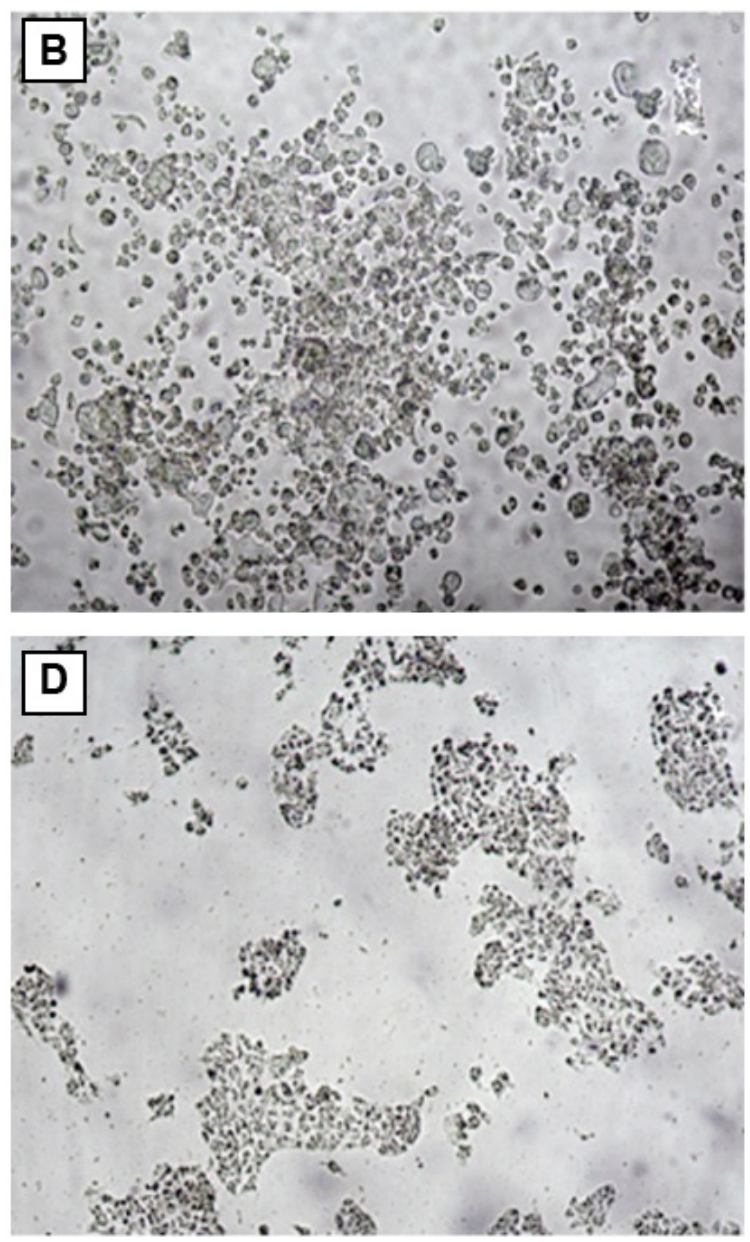

Figure 8 Inverted microscopic image of HT29 (A) control cells, (B) Gymnema sylvestre-treated (85 $\mu \mathrm{g} / \mathrm{mL})$, (C) silver nanoparticle-treated (83 $\mu \mathrm{g} / \mathrm{mL})$, and (D) silver nanoparticle-treated $(85 \mu \mathrm{g} / \mathrm{mL})$ cells. 
sylvestre, while Chan has identified the presence of acylation with diangeloyl groups at the $\mathrm{C} 21-22$ positions in triterpenoid saponins, which is essential for cytotoxcity toward tumor cells. ${ }^{77}$ Tang et al ${ }^{78}$ have reported that saponin could induce apoptosis of U251 cells, and both BAD-mediated intrinsic apoptotic signaling pathway and caspase-8-mediated extrinsic apoptotic signaling pathway were involved in the apoptosis.

The promising saponins were further studied as potential anticancer agents by many researchers. Ai et al ${ }^{79}$ proposed a qualitative method that can be used to recognize the presence or absence of cancer cells with gold NPs for targeted cancer cell imaging and efficient photodynamic therapy. As reported by Raghavendra et a ${ }^{80}$ the size effects and multifunctionality are the main characteristics of NPs, so our method of one-step synthesis of SNPs using the aqueous extract of $G$. sylvestre may serve as a potential anticancer drug for cancer therapy. Further studies have to be carried out to understand the nature of cytotoxicity and the death or proliferation of cells caused by GSNPs from G. sylvestre leaf extract.

\section{Conclusion}

The green synthesis of biofunctionalized SNPs from the leaves of $G$. sylvestre was economical, nontoxic, and environmentally benign. Due to the reducing and capping nature of the bioactive phytocompounds present in the aqueous extract of $G$. sylvestre, a cap was formed around the silver ions of the biofunctionalized SNPs which were stable. The presence of the functional group of the bioactive compounds was confirmed by FTIR spectra. The particle size and the spherical shape of the SNPs were determined by XRD and SEM analyses. Since the plant extract and the biofunctionalized SNPs showed anticancer activity against cancer cells, G. sylvestre may serve as a source for potential anticancer drugs. The present study showed the anticancer activities of both the bioactive compounds of the leaf extract and the biofunctionalized SNPs synthesized against HT29 human adenocarcinoma cells in vitro. Our studies provide an important basis for the application of NPs for in vitro anticancer activity against human colon adenocarcinoma cells. Our earlier reports have also shown the potential antiulcer properties of G. sylvestre in mice. ${ }^{13}$ So GSS is a good plant candidate for further studies in alternative medicine due its multifunctional medical properties

\section{Acknowledgment}

The authors gratefully acknowledge the management, SRM University, for providing the facilities and supporting the work.

\section{Disclosure}

The authors declare no conflicts of interest in this work.

\section{References}

1. Grover JK, Yadav S, Vats V. Medicinal plants of India with anti-diabetic potential. J Ethnopharmacol. 2002;81(1):81-100.

2. Ayyanar M, Ignacimuthu S. Ethnobotanical survey of medicinal plants commonly used by Kani tribals in Tirunelveli hills of Western Ghats, India. J Ethnopharmacol. 2011;134(3):851-864.

3. Pedersen ME, Vestergaard HT, Hansen SL, Bah S, Diallo D, Jäger AK. Pharmacological screening of Malian medicinal plants used against epilepsy and convulsions. J Ethnopharmacol. 2009;121(3): 472-475.

4. Karthic R, Nagaraj S, Arulmurugan P, Seshadri S, Rengasamy R, Kathiravan K. Gymnema sylvestre R. Br. suspension cell extract show antidiabetic potential in Alloxan induced diabetic albino male rats. Asian Pac J Trop Biomed. 2012;2(2):S930-S933.

5. Wu X, Mao G, Fan Q, et al. Isolation, purification, immunological and anti-tumor activities of polysaccharides from Gymnema sylvestre. Food Res Int. 2012;48(2):935-939.

6. Kanetkar P, Singhal R, Kamat M. Gymnema sylvestre: a memoir. J Clin Biochem Nat. 2007;41(September):77-81.

7. Chattopadhyay RR. Possible mechanism of antihyperglycemic effect of Gymnema sylvestre leaf extract, part I. Gen Pharmacol. 1998;31(3):495-496.

8. Patel K, Gadewar M, Tripathi R. Pharmacological and analytical aspects of gymnemic acid: a concise report. Asian Pac J Trop Dis. 2012; 2(5):414-416.

9. Satdive RK, Abhilash P, Fulzele DP. Antimicrobial activity of Gymnema sylvestre leaf extract. Fitoterapia. 2003;74(7-8):699-701.

10. Preuss HG, Bagchi D, Bagchi M, Rao CVS, Dey DK, Satyanarayana S. Effects of a natural extract of (-)-hydroxycitric acid (HCA-SX) and a combination of HCA-SX plus niacin-bound chromium and Gymnema sylvestre extract on weight loss. Diabetes Obes Metab. 2004;6(3): 171-180.

11. Manvi F, Malik J, Alagawadi K, Noolvi M. Evaluation of anti-inflammatory activity of Gymnema sylvestre leaves extract in rats. Int J Green Pharm. 2008;2(2):114-115.

12. Yadav M, Lavania A, Tomar R, Prasad GBKS, Jain S, Yadav H. Complementary and comparative study on hypoglycemic and antihyperglycemic activity of various extracts of Eugenia jambolana seed, Momordica charantia fruits, Gymnema sylvestre, and Trigonella foenum graecum seeds in rats. Appl Biochem Biotechnol. 2010;160(8):2388-2400.

13. Arun LB, Arunachalam AM, Arunachalam KD, Annamalai SK, Amit Kumar K. In vivo anti-ulcer, anti-stress, anti-allergic, and functional properties of Gymnemic acid isolated from Gymnema sylvestre R Br. BMC Complement Altern Med. 2014;14(1):70.

14. Thakur GS, Sharma R, Sanodiya BS, Pandey M, Prasad G, Bisen PS. Gymnema sylvestre: an alternative therapeutic agent for management of diabetes. J Appl Pharm Sci. 2012;2(12):1-6.

15. Manni PE, Sinsheimer JE. Constituents from Gymnema sylvestre leaves. J Pharm Sci. 1965;54(10):1541-1544.

16. Nakamura Y, Tsumura Y, Tonogai Y, Shibata T. Fecal steroid excretion is increased in rats by oral administration of gymnemic acids contained in Gymnema sylvestre leaves. J Nutr. 1999;129:1214-1222.

17. Arunachalam KD, Arun LB, Annamalai SK, Arunachalam AM. Biofunctionalized gold nanoparticles synthesis from Gymnema Sylvestre and its preliminary anticancer activity. Int J Pharm Pharm Sci. 2014;6(4):423-430.

18. Sharma K, Singh U, Vats S, Priyadarsini K, Bhatia A, Kamal R. Evaluation of evidenced-based radioprotective efficacy of Gymnema sylvestre leaves in mice brain. J Environ Pathol Toxicol Oncol. 2009; 28(4):311-323.

19. Patel SS, Shah RS, Goyal RK. Antihyperglycemic, antihyperlipidemic and antioxidant effects of Dihar, a polyherbal ayurvedic formulation in streptozotocin induced diabetic rats. Indian J Exp Biol. 2009; 47(7):564-570.

20. Kang M-H, Lee MS, Choi M-K, Min K-S, Shibamoto T. Hypoglycemic activity of Gymnema sylvestre extracts on oxidative stress and antioxidant status in diabetic rats. J Agric Food Chem. 2012;60(10): $2517-2524$ 
21. Srikanth AV, Maricar S, Lakshmi MN, Ravi Kumar P, Madhava Reddy B. Anticancer activity of Gymnema sylvestre $\mathrm{R}$. Br. Int J Pharm Sci Nanotechnol. 2010;3(1):2-4.

22. Amaki HT, Atoh HS, Ori SH. Inhibitory effects of herbal extracts on breast cancer resistance protein (BCRP) and structure-inhibitory potency relationship of isoflavonoids. Drug Metab Pharmacokinet. 2010;25(2):170-179.

23. Khanna V, Kannabiran K. Anticancer-cytotoxic activity of saponins isolated from the leaves of gymnema sylvestre and eclipta prostrata on HeLa cells. Int J Green Pharm. 2009;3(3):227-229.

24. Baskaran K, Ahamath BK, Shanmugasundaram KR, Shanmugasundaram ERB. Antidiabetic effect of a leaf extract from Gymnema sylvestre in non-insulin-dependent diabetes mellitus patients. J Ethnopharmacol. 1990;30(3):295-305.

25. Shanmugasundaram ERB, Rajeswari G, Baskaran K, Kumar BRR, Shanmugasundaram KR, Ahmath BK. Use of Gymnema sylvestre leaf extract in the control of blood glucose in insulin-dependent diabetes mellitus. J Ethnopharmacol. 1990;30(3):281-294.

26. Meiselman HL, Halpern BP. Effects of Gymnema sylvestre on complex tastes elicited by amino acids and sucrose. Physiol Behav. 1970;5(12):1379-1384.

27. Ananthan R, Latha M, Ramkumar KM, Pari L, Baskar C, Narmatha Bai V.Modulatory effects of Gymnema montanum leaf extract on alloxan-induced oxidative stress in Wistar rats. Nutrition. 2004; 20(3):280-285.

28. El Shafey AAM, El-Ezabi MM, Seliem MME, Ouda HHM, Ibrahim DS. Effect of Gymnema sylvestre R. Br. leaves extract on certain physiological parameters of diabetic rats. J King Saud Univ-Sci. 2013;25(2):135-141.

29. Leach MJ. Gymnema sylvestre for diabetes mellitus: a systematic review. J Altern Complement Med. 2007;13(9):977-983.

30. Ramkumar KM, Vanitha P, Uma C, Suganya N, Bhakkiyalakshmi E, Sujatha J. Antidiabetic activity of alcoholic stem extract of Gymnema montanum in streptozotocin-induced diabetic rats. Food Chem Toxicol. 2011;49(12):3390-3394.

31. Ahmed AB, Rao AS, Rao MV. In vitro callus and in vivo leaf extract of Gymnema sylvestre stimulate $\beta$-cells regeneration and anti-diabetic activity in Wistar rats. Phytomedicine. 2010;17(13):1033-1039.

32. Mahdi A, Chandra A, Singh R, Shukla S, Mishra LC, Ahmad S. Effect of herbal hypoglycemic agents on oxidative stress and antioxidant status in diabetic rats. Indian J Clin Biochem. 2003;18(2):8-15.

33. Goix S, Lévêque T, Xiong TT, et al. Environmental and health impacts of fine and ultrafine metallic particles: assessment of threat scores. Environ Res. 2014;133(0):185-194.

34. Boholm M, Arvidsson R. Controversy over antibacterial silver: implications for environmental and sustainability assessments. J Clean Prod. 2014;68(0):135-143.

35. Barua S, Konwarh R, Bhattacharya SS, et al. Non-hazardous anticancerous and antibacterial colloidal "green" silver nanoparticles. Colloids Surf B Biointerfaces. 2013;105(0):37-42.

36. Jin G, Prabhakaran MP, Kai D, Annamalai SK, Arunachalam KD, Ramakrishna S. Tissue engineered plant extracts as nanofibrous wound dressing. Biomaterials. 2013;34(3):724-734.

37. Elavazhagan T, Arunachalam KD. Memecylon edule leaf extract mediated green synthesis of silver and gold nanoparticles. Int J Nanomedicine. 2011;6:1265-1278.

38. Parekh J, Chanda SV. In vitro antimicrobial activity and phytochemical analysis of some Indian medicinal plants. Turk J Biotechnol. 2008;31:53-58.

39. Arunachalam KD, Subhashini S, Annamalai SK. Wound healing and antigenotoxic activities of Aegle marmelos with relation to its antioxidant properties. J Pharm Res. 2012;5(3):1492-1502.

40. Guruvaiah P, Arunachalam A, Velan LPT. Evaluation of phytochemical constituents and antioxidant activities of successive solvent extracts of leaves of Indigofera caerulea Roxb using various in vitro antioxidant assay systems. Asian Pac J Trop Dis. 2012;2:S118-S123.
41. Cieśla Ł, Kryszeń J, Stochmal A, Oleszek W, Waksmundzka-Hajnos M. Approach to develop a standardized TLC-DPPH• test for assessing free radical scavenging properties of selected phenolic compounds. J Pharm Biomed Anal. 2012;70:126-135.

42. Von White G 2nd, Kerscher P, Brown RM, et al. Green synthesis of robust, biocompatible silver nanoparticles using garlic extract. J Nanomater. 2012;2012:1-12.

43. Shameli K, Ahmad MB, Zamanian A, et al. Green biosynthesis of silver nanoparticles using Curcuma longa tuber powder. Int J Nanomedicine. 2012;7:5603-5610.

44. Dipankar C, Murugan S. The green synthesis, characterization and evaluation of the biological activities of silver nanoparticles synthesized from Iresine herbstii leaf aqueous extracts. Colloids Surf B Biointerfaces. 2012;98:112-119.

45. Arunachalam KD, Annamalai SK, Arunachalam AM, Kennedy S. One step green synthesis of phytochemicals mediated gold nanoparticles from Aegle marmales for the prevention of urinary catheter infection. Int J Pharm Pharm Sci. 2014;6(1):700-706.

46. Arunachalam KD, Annamalai SK. Chrysopogon zizanioides aqueous extract mediated synthesis, characterization of crystalline silver and gold nanoparticles for biomedical applications. Int J Nanomedicine. 2013;8:2375-2384.

47. Arunachalam KD, Annamalai SK, Hari S. One-step green synthesis and characterization of leaf extract-mediated biocompatible silver and gold nanoparticles from Memecylon umbellatum. Int J Nanomedicine. 2013;8:1307-1315.

48. Vasanth K, Ilango K, Mohankumar R, Agrawal A, Dubey GP. Anticancer activity of Moringa oleifera mediated silver nanoparticles on human cervical carcinoma cells by apoptosis induction. Colloids Surf B Biointerfaces. 2014;117C:354-359.

49. Mateos R, Pereira-Caro G, Bacon JR, et al. Anticancer activity of olive oil hydroxytyrosyl acetate in human adenocarcinoma caco-2 cells. J Agric Food Chem. 2013;61(13):3264-3269.

50. Arunachalam KD, Annamalai SK, Arunachalam AM, Kennedy S. Green synthesis of crystalline silver nanoparticles using Indigofera aspalathoides-medicinal plant extract for wound healing applications. Asian J Chem. 2013;25(suppl):S311-S314.

51. Akhtar MS, Panwar J, Yun Y-S. Biogenic synthesis of metallic nanoparticles by plant extracts. ACS Sustain Chem Eng. 2013;1(6):591-602.

52. Suman TY, Radhika Rajasree SR, Ramkumar R, Rajthilak C, Perumal P. The green synthesis of gold nanoparticles using an aqueous root extract of Morinda citrifolia L. Spectrochim Acta A Mol Biomol Spectrosc. 2014;118:11-16.

53. Kim ST, Kim HK, Han SH, Jung EC, Lee S. Determination of size distribution of colloidal $\mathrm{TiO}_{2}$ nanoparticles using sedimentation field-flow fractionation combined with single particle mode of inductively coupled plasma-mass spectrometry. Microchem J. 2013;110:636-642.

54. Arunachalam KD, Annamalai SK, Baskaran KV, Rajaram S, Jha SK, Sreedevi. Spatial and multivariate analysis of trace elements in the surface water and deep sediments of fresh water aquatic ecosystem. Am J Environ Sci. 2014;10(2):102-122.

55. Jayaseelan C, Ramkumar R, Rahuman AA, Perumal P. Green synthesis of gold nanoparticles using seed aqueous extract of Abelmoschus esculentus and its antifungal activity. Ind Crops Prod. 2013; 45(0):423-429.

56. Sujitha MV, Kannan S. Green synthesis of gold nanoparticles using Citrus fruits (Citrus limon, Citrus reticulata and Citrus sinensis) aqueous extract and its characterization. Spectrochim Acta A Mol Biomol Spectrosc. 2013;102(0):15-23.

57. Loo YY, Chieng BW, Nishibuchi M, Radu S. Synthesis of silver nanoparticles by using tea leaf extract from Camellia sinensis. Int J Nanomedicine. 2012;7:4263-4267.

58. Ghosh S, Patil S, Ahire M, et al. Synthesis of silver nanoparticles using Dioscorea bulbifera tuber extract and evaluation of its synergistic potential in combination with antimicrobial agents. Int J Nanomedicine. 2012;7:483-496. 
59. Khan M, Khan M, Adil SF, et al. Green synthesis of silver nanoparticles mediated by Pulicaria glutinosa extract. Int J Nanomedicine. 2013;8:1507-1516.

60. Shameli K, Ahmad MB, Zamanian A, et al. Green biosynthesis of silver nanoparticles using Curcuma longa tuber powder. Int J Nanomedicine. 2012;7:5603-5610.

61. He Y, Du Z, Lv H, et al. Green synthesis of silver nanoparticles by Chrysanthemum morifolium Ramat. extract and their application in clinical ultrasound gel. Int J Nanomedicine. 2013;8:1809-1815.

62. Pasupuleti VR, Prasad, Shiekh RA, et al. Biogenic silver nanoparticles using Rhinacanthus nasutus leaf extract: synthesis, spectral analysis, and antimicrobial studies. Int J Nanomedicine. 2013;8:3355-3364.

63. Arokiyaraj S, Arasu MV, Vincent S, et al. Rapid green synthesis of silver nanoparticles from Chrysanthemum indicum $\mathrm{L}$ and its antibacterial and cytotoxic effects: an in vitro study. Int $J$ Nanomedicine. 2014;9:379-388.

64. Ramamurthy CH, Padma M, samadanam ID, et al. The extra cellular synthesis of gold and silver nanoparticles and their free radical scavenging and antibacterial properties. Colloids Surf B Biointerfaces. 2013;102:808-815.

65. Prabhu D, Arulvasu C, Babu G, Manikandan R, Srinivasan P. Biologically synthesized green silver nanoparticles from leaf extract of Vitex negundo L. induce growth-inhibitory effect on human colon cancer cell line HCT15. Process Biochem. 2013;48(2):317-324.

66. Zhang Y, Cheng X, Zhang Y, Xue X, Fu Y. Biosynthesis of silver nanoparticles at room temperature using aqueous aloe leaf extract and antibacterial properties. Colloids Surf A Physicochem Eng Aspects. 2013; 423:63-68.

67. Karuppiah M, Rajmohan R. Green synthesis of silver nanoparticles using Ixora coccinea leaves extract. Mater Lett. 2013;97:141-143.

68. Nazeruddin GM, Prasad NR, Prasad SR, Garadkar KM, Nayak AK. In-vitro bio-fabrication of silver nanoparticle using Adhathoda vasica leaf extract and its anti-microbial activity. Phys E Low-Dimens Syst Nanostruct. 2014;61:56-61.

69. Vijay Kumar PPN, Pammi SVN, Kollu P, Satyanarayana KVV, Shameem U. Green synthesis and characterization of silver nanoparticles using Boerhaavia diffusa plant extract and their anti bacterial activity. Ind Crops Prod. 2014;52:562-566.
70. Raja K, Saravanakumar A, Vijayakumar R. Efficient synthesis of silver nanoparticles from Prosopis juliflora leaf extract and its antimicrobial activity using sewage. Spectrochim Acta A Mol Biomol Spectrosc. 2012;97:490-494.

71. Ponarulselvam S, Panneerselvam C, Murugan K, Aarthi N, Kalimuthu K, Thangamani S. Synthesis of silver nanoparticles using leaves of Catharanthus roseus Linn. G. Don and their antiplasmodial activities. Asian Pac J Trop Biomed. 2012;2(7):574-580.

72. Suman TY, Radhika Rajasree SR, Kanchana A, Elizabeth SB. Biosynthesis, characterization and cytotoxic effect of plant mediated silver nanoparticles using Morinda citrifolia root extract. Colloids Surf B Biointerfaces. 2013;106:74-78.

73. Vijayakumar M, Priya K, Nancy FT, Noorlidah A, Ahmed ABA. Biosynthesis, characterisation and anti-bacterial effect of plant-mediated silver nanoparticles using Artemisia nilagirica. Ind Crops Prod. 2013; 41:235-240

74. Meenakumari S, Arunachalam KD, Annamalai SK. Screening and characterisation of silver nanoparticles for the prevention of biofilm in urinary catheters. Asian J Chem. 2013;25(suppl):S347-S349.

75. Kruszewski M, Grądzka I, Bartłomiejczyk T, et al. Oxidative DNA damage corresponds to the long term survival of human cells treated with silver nanoparticles. Toxicol Lett. 2013;219(2):151-159.

76. Sahu NP, Mahato SB, Sarkar SK, Poddar G. Triterpenoid saponins from Gymnema sylvestre. Phytochemistry. 1996;41(4):1181-1185.

77. Chan P-K. Acylation with diangeloyl groups at $\mathrm{C} 21-22$ positions in triterpenoid saponins is essential for cytotoxcity towards tumor cells. Biochem Pharmacol. 2007;73(3):341-350.

78. Tang HF, Lin HW, Chen XL, Cheng G, Zhao YP, Wen AD. Cytotoxic triterpenoid saponins from Ardisia pusilla. Chinese Chem Lett. 2009;20(2):193-196.

79. Ai J, Xu Y, Lou B, Li D, Wang E. Multifunctional AS1411-functionalized fluorescent gold nanoparticles for targeted cancer cell imaging and efficient photodynamic therapy. Talanta. 2014;118(0):54-60.

80. Raghavendra R, Arunachalam K, Annamalai SK, Arunachalam AM Diagnostics and therapeutic application of Gold nanoparticles. Int J Pharm Pharm Sci. 2014;6(suppl 2):74-87.
International Journal of Nanomedicine

\section{Publish your work in this journal}

The International Journal of Nanomedicine is an international, peerreviewed journal focusing on the application of nanotechnology in diagnostics, therapeutics, and drug delivery systems throughout the biomedical field. This journal is indexed on PubMed Central,

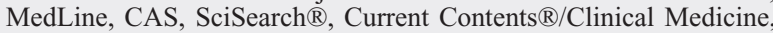

\section{Dovepress}

Journal Citation Reports/Science Edition, EMBase, Scopus and the Elsevier Bibliographic databases. The manuscript management system is completely online and includes a very quick and fair peer-review system, which is all easy to use. Visit http://www.dovepress.com/ testimonials.php to read real quotes from published authors. 